and facilitate the evaluation of conservation policies and methods.

20. Military activity damaging to Nature should be avoided.

21. States and, to the extent that they are able, public authorities, international organizations, individuals, groups, and corporations, shall:

(a) Cooperate in the task of conserving Nature through common activities and other relevant actions, including information exchange and consultation;

(b) Establish standards for products and processes that may adversely affect Nature, as well as agreed methodologies for assessing their effects;

(c) Implement the applicable international legal provisions for conservation of Nature and environmental protection;

(d) Ensure that activities within their jurisdictions or control do not cause damage to natural systems located within other States or in the areas beyond the limits of national jurisdiction; and

(e) Safeguard and conserve Nature in areas beyond national jurisdiction.

22. Taking fully into account the sovereignty of States over their natural resources, each State shall give effect to the provisions of this Charter through its component organs and in cooperation with other States.

23. All persons, in accordance with national law, shall have the opportunity to participate, singly or with others, in the process leading to the formulation of decisions which directly concern their environment, and shall have access to means of redress when their environment has suffered damage or deterioration.

24. Each person has a duty to act in accordance with the provisions of this Charter; acting alone, in groups, or through the political process, each person shall strive to ensure that the objectives and requirements of this Charter are met.

\section{Tasmania's Proposed Dams in Its South-West Wilderness}

The alarm caused by the Hydro-electric Commission's plan to flood the Franklin and other valleys in SouthWest Tasmania has now spread to the whole of Australia and is keenly felt in conservationist circles all over the World. The wilderness of South-West Tasmania contains one of the few remaining temperate rain-forests of the globe that are still relatively undisturbed, and the portion of it that holds the greatest interest for scientists is precisely the valleys where, owing inter alia to very high moisture, the flora is exceptional. Besides the many interesting plants which are endemic to the Central Plateau and western and South-West Tasmania, a list of some thirty species has been drawn up (including the wellknown Huon Pine, Dacrydium franklinii) which are unique to the region.*

It is always difficult, when practical interests are involved, to obtain a hearing for arguments along such general lines as the protection of the Biosphere or even

* These include the 23 listed by Kedar N. Baidya on page 60 of this issue as 'likely to be endangered through inundation by the [Franklin] dam impoundment' - See that article for further details, and a longer paper from another source for which we hope to find space in an early issue.-Ed. for pressing appeals from the world of science. The irritation felt by some Tasmanians at any intrusion into what they feel to be their private affairs is perhaps understandable, and it is unfortunate that the problem was allowed to become a political one instead of being confined to dispassionate discussion among men of good will. One can only pray that the efforts made by the Federal Government to find a reasonable, negotiated solution satisfactory to all parties will be successful, thus preserving a region which UNESCO recently declared to be an essential part of the 'World Heritage'.

Roger de Candolle, President International Dendrology Society 41 Chemin du Vallon Chêne-Bougeries 1224 Geneva, Switzerland.

\section{New Director-General for IUCN}

The International Union for Conservation of Nature and Natural Resources (IUCN) has elected as its new Director-General Dr Kenton R. Miller, who will assume the post in the World Conservation Centre, at Gland, Switzerland, in July 1983. Dr Miller is currently Director of the Center for Strategic Wildland Management Studies and Associate Professor of Natural Resources at the University of Michigan, Ann Arbor, Michigan. He is Chairman of the IUCN Commission on National Parks and Protected Areas** and a member of the IUCN Species Survival Commission as well as of the Union's Programme Planning Advisory Group.

Dr Miller has spent more than twenty years in the exacting field of conservation, and has worked with various international bodies - including the United $\mathrm{Na}$ tions Food and Agriculture Organization (FAO), with whom in Rome, Italy, he was responsible for national parks and wildlife management. Later, in Santiago, Chile, he developed and directed FAO's Wildlands and Environmental Conservation Programme for Latin America and the Caribbean. He has carried out missions and consultancies for international organizations -including FAO, UNESCO, and UNEP - in various parts of the world. Most recently, he has served as a consultant to UNEP on the development of the World Charter for Nature ${ }^{+}$and on environmental policy to the World Bank.

Recently (in October 1982) Dr Miller was the Secretary-General of the World National Parks Congress, held in Bali, Indonesia ${ }^{++}$, which brought together over 500 experts from 70 nations to define the expanded role for protected areas inter alia in implementing the goals of the World Conservation Strategy. Dr Miller has also carried out field-work very widely in Latin America and the Caribbean, Africa, and Asia, and is the author of numerous articles and books -including a textbook on concepts and techniques for the management of wildlands.

** As such he contributed, with the Commission's Executive Officer Jeffrey A. McNeely, the key paper on 'IUCN, National Parks, and Protected Areas: Priorities for Action' which is published on pp. 13-21 of this issue.--Ed.

+ Printed on pp. 67--8 of this issue.--Ed.

++ See the account by Raisa Scriabine on pp. 78-9 of this issue.--Ed. 